\title{
Recent geodetic mass balance and extent changes of very small glaciers in the Hulugou Basin, Central Qilian Mountains, China
}

\author{
Chunhai Xu ${ }^{1,2}, *$, Zhongqin Li $^{1}$, Feiteng WAng $^{1}$, Lin $\mathrm{HA}^{3}$, Yousif Elnour Yagoub ${ }^{1,4}$ \\ and SHUANG JiN ${ }^{1}$ \\ ${ }^{1}$ State Key Laboratory of Cryospheric Science/Tien Shan Glaciological Station, Northwest Institute of \\ Eco-Environment and Resources, Chinese Academy of Sciences, Lanzhou 730 000, People's Republic of China. \\ ${ }^{2}$ University of Chinese Academy of Sciences, Beijing 100 049, People's Republic of China. \\ ${ }^{3}$ School of Geographical Sciences, Southwestern University, Chongqing 400 715, People's Republic of China. \\ ${ }^{4}$ Department of Forest Protection and Conservation, Faculty of Forestry, University of Khartoum, \\ Shambat, Sudan. \\ *Corresponding author.e-mail: xuchunhai716@163.com
}

MS received 16 November 2017; revised 5 June 2018; accepted 6 June 2018; published online 23 February 2019

Very small glaciers $\left(<0.5 \mathrm{~km}^{2}\right)$ account for more than $70 \%$ of the total number of glaciers in the Qilian Mountains. Despite their total area and volume being small, they are important water resources in the Hexi Corridor. While glacier monitoring mostly focuses on medium-sized and large valley glaciers (e.g., Qiyi Glacier and Laohugou Glacier No. 12) in the Qilian Mountains, little is known about very small glacier mass balance in this region. This study presents a geodetic mass balance of six very small glaciers in the Hulugou Basin by comparing Shuttle Radar Topography Mission (SRTM) C-band (2000) and airborne laser scanning (2012) digital elevation models (DEMs). The total glaciers' area decreased by $23.6 \%$ at a rate of $0.024 \mathrm{~km}^{2} \mathrm{a}^{-1}$ and the geodetic mass balance was $-0.68 \pm 0.11 \mathrm{~m}$ water equivalent (m w.e.) $\mathrm{a}^{-1}$ from 2000 to 2012. Shiyi Glacier, as the monitored glacier in the Basin, had lost $10.9 \%$ of the surface area at a rate of $0.005 \mathrm{~km}^{2} \mathrm{a}^{-1}$ and the geodetic mass balance was $-0.53 \pm 0.11 \mathrm{~m}$ w.e. $\mathrm{a}^{-1}$ for the period. Climatic variations over the last decade showed a pronounced increase in summer temperatures. The warmer conditions probably explain the glaciers mass loss observed in the Hulugou Basin.

Keywords. Geodetic mass balance; ALS point cloud; SRTM C-band DEM; very small glaciers; Hulugou Basin.

\section{Introduction}

Mountain glaciers are important fresh water resources and they supply melt water to many river systems, which is well reflected in the arid region of northwest China. Changes in glaciers, especially changes in glacier mass, provide important information to understand climate-glacier interactions and its consequences such as regional water resource estimation and sea level rise (IPCC 2013). Modern series of annual or seasonal measurements of glacier-wide mass balance were started in the late 1940s (WGMS 2017). The direct glaciological method determines mass balance based on stake and snow pit measurements; the net accumulation is measured by digging pits in the 
area where snow is accumulated and stakes are drilled into the glacier in the ablation area to derive ablation (Cogley et al. 2011). The glaciological method provides quantitative results at high temporal resolution (Zemp et al. 2015), which usually is limited to individual glaciers. It is laborious and time consuming for us to sustain long-term direct measurements, up-to-date ongoing mass-balance series as more than $30 \mathrm{yr}$ of observations are available for only 41 reference glaciers (WGMS 2017). In the Qilian Mountains, only Qiyi Glacier has discontinuous glaciological mass-balance data $(\mathrm{Pu}$ et al. 2005).

In comparison to in-situ annual and sometimes seasonal measurements using the glaciological method, the geodetic method provides overall glacier volume changes over a longer time period by repeated mapping from ground, air or space-borne surveys and subsequent differencing of multi-temporal digital elevation models (DEMs) of glacier surface topography (Zemp et al. 2013). The geodetic results allow extending the glaciological sample both in space and time, which has become a widely used method to calculate glacier mass balance and evaluate the contribution of glaciers to runoff, and if necessary, periodically validate and calibrate long-term glaciological mass-balance series (Cogley 2009; Cogley et al. 2011; Zemp et al. 2013). In the last few years, generations of airborne and terrestrial light detection and ranging (LiDAR) techniques have offered dense point clouds and high-resolution and -precision DEMs of glacier surface (Joerg et al. 2012; Helfricht et al. 2014; Piermattei et al. 2015). Usually, airborne and terrestrial LiDAR have error margins in the order of a few centimetres (Hartzell et al. 2015). Previous studies indicate that the accuracy of geodetic mass balance resulting from the accuracy of the DEMs ranges from $2 \mathrm{~m}$ water equivalent ( $\mathrm{m}$ w.e.) for photogrammetric data to $0.002 \mathrm{~m}$ w.e. for LiDAR data (Fischer 2011).

Very smaller glaciers (here defined as being smaller than $0.5 \mathrm{~km}^{2}$ ) are the most numerous ( $>70 \%$ of the total glacier number) in the Qilian Mountains and western China (Liu et al. 2015). However, those glaciers have received little attention in glaciological research so far and little is known about the response of very small glaciers to atmospheric warming (Huss and Fischer 2016). Due to the large number and reacting quickly to environmental changes, very small glaciers play significant role at the larger scale, such as their impact on water resources and global sea level rise. At present relevant studies about very small glaciers are very less in China and in-situ measurements are still sparse, which means that there is a lot of unknown information about very small glaciers. In the present study, we use airborne laser scanning (ALS) data and SRTM C-band DEM to estimate the geodetic mass balance of six very small glaciers in the Hulugou Basin, Central Qilian Mountains, from 2000 to 2012.

\section{Study area}

The Qilian Mountains are located in the northeast margin of the Tibetan Plateau. This paper focuses on the central part of the Qilian Mountains, the upstream watershed of Heihe River (figure 1a), which is defined as drainage basin above Yingluoxia. Heihe River Watershed is the second largest inland river in the arid region of northwest China with the main stream stretching $821 \mathrm{~km}$ in length. The total area of the catchment is $10,009 \mathrm{~km}^{2}$ with an altitude ranging from 1668 to $5573 \mathrm{~m}$ a.s.l. Mountain glaciers are widely distributed above $4000 \mathrm{~m}$ a.s.l. of the upstream watershed. According to the second Glacier Inventory of China (GIC), there are 952 glaciers in the Heihe River Watershed (including Beida River catchment), with a covering area of $293.60 \mathrm{~km}^{2}$ and storing an ice volume of $11.14 \mathrm{~km}^{3}$, respectively (Sun et al. 2015).

Hulugou Basin $\left(38.20-38.28^{\circ} \mathrm{N} ; 99.83-99.90^{\circ} \mathrm{E}\right)$ is a small alpine catchment, with an altitude ranging from 2960 to $4800 \mathrm{~m}$ a.s.l. Because this region covers about $92 \%$ of the upstream region of Heihe River Watershed and nearly all typical underlying surfaces in high cold regions, Hulugou Basin can be set as an ideal and representative study site for long-term field measurements. The basin has a gourd shape with a total area of $22.5 \mathrm{~km}^{2}$ and there were six glaciers with a total area of $1.45 \mathrm{~km}^{2}$ in 1956 according to the first GIC. Shiyi Glacier was the largest glacier with an area of $0.49 \mathrm{~km}^{2}$ in 2012 (figure 1b). The average glacier area is about $0.30 \mathrm{~km}^{2}$ in the Heihe River Basin and $0.60 \mathrm{~km}^{2}$ in the Qilian Mountains, respectively, with very small glaciers leading (Sun et al. 2015). The shape types are dominated by hanging and small cirquevalley glaciers. In the view of various parameters, Shiyi Glacier is a small valley glacier with the characteristics of continental-type glaciers. Hence, it is significant for us to study the mass balance of Shiyi Glacier and the glaciers in the Hulugou Basin. 


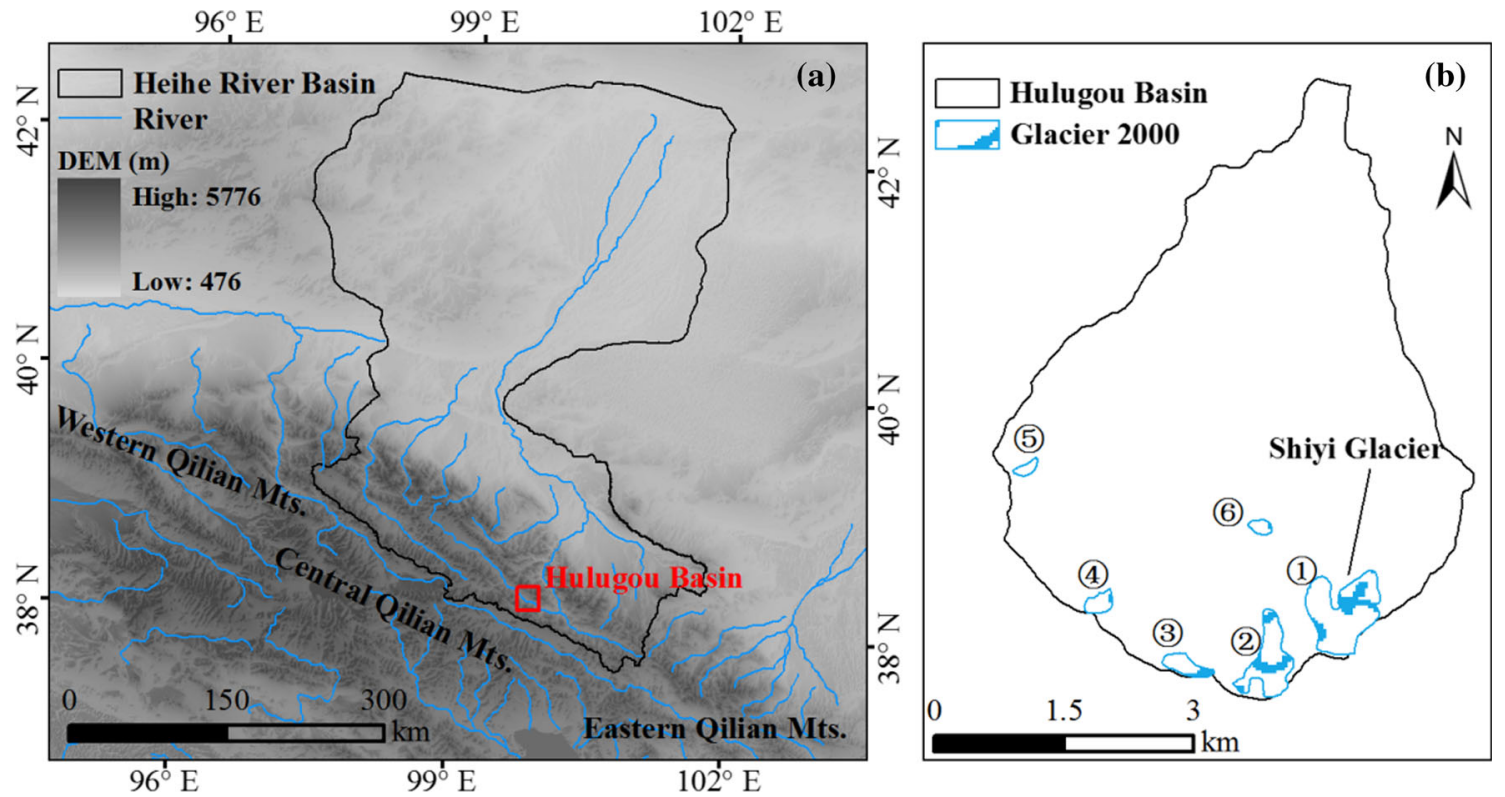

Figure 1. An overview of the study area: (a) location of Hulugou Basin in the Central Qilian Mountains and the upper stream of Heihe River Watershed and (b) the distribution of glacier in Hulugou Basin.

\section{Data and methodology}

\subsection{Data sources}

ALS data, DEM, Landsat images and metrological data are used in the present study.

\subsubsection{ALS point cloud data}

ALS is a modern topographic surveying technique, which measures the object distance based on the time-of-flight principle, and a typical laser scanner includes the following key units: laser ranging unit, opto-mechanical scanner and control and processing unit (Wehr and Lohr 1999). In the support of 'HiWATER: An Integrated Remote Sensing Experiment on Hydrological and Ecological Process in the Heihe River Basin', using Y-12 helicopter and carrying ALS70, which were made by Leica corporation, an airborne remote sensing test flight was implemented in the Hulugou Basin on 25 July 2012 (Li et al. 2012). The highest flight altitude of the system is about $5000 \mathrm{~m}$ a.s.l., the maximum impulse frequency is $500 \mathrm{kHz}$, the maximum scanning angle and frequency are $75^{\circ}$ and $200 \mathrm{kHz}$, respectively. ALS70 (with a built-in digital camera) uses a longer near-infrared wavelength $(1064 \mathrm{~nm})$ such that high rates of reflection $(>80 \%)$ from snow- and ice-covered terrains are theoretically possible and can record multiple echo intensity. The number of laser footprints in the Hulugou Basin is 34,007,198 and the average density is 1 point per square metre. ALS70 allows the acquisition of DEM with a vertical accuracy of $5-30 \mathrm{~cm}$. The data originates from Cold and Arid Region Sciences Data Center at Lanzhou (http://westdc.westgis.ac.cn/).

\subsubsection{SRTM C-band DEM and Landsat images}

During the single-pass interferometric synthetic aperture radar Shuttle Radar Topography Mission in February 2000, the SRTM C-band DEM was derived from C-band radar interferometry with a spatial resolution of $3 \operatorname{arcsec}(90 \mathrm{~m})$. The SRTM is freely available (http://earthexplorer.usgs.gov/) for scientific research with the coordinate system of the World Geodetic System 1984 (WGS84) defined as the Earth Gravitational Model 1996 (EGM 96). The vertical accuracy is specified as $6 \mathrm{~m}$ relatively and $16 \mathrm{~m}$ absolutely (Rabus et al. 2003), but some studies have shown that the accuracy in flat areas was better than $10 \mathrm{~m}$ and significantly dependent on the topography. Because of the coverage and accuracy of SRTM3, it has been widely used to estimate local and regional glacier mass balance (Muskett et al. 2003). In addition, Landsat TM/ETM+ images without clouds and little seasonal snow were selected to extract accurate boundary of the six very small glaciers in 2000 and 2012 (table 1). The images are freely available from United States Geological Survey (USGS, http:// www.glovis.usgs.gov/). Scenes had been corrected 
Table 1. Selected Landsat TM and ETM+ images used to extract glacier boundary.

\begin{tabular}{lclcr}
\hline ID & $\begin{array}{c}\text { Data } \\
\text { (yyyy-mm-dd) }\end{array}$ & Sensor & $\begin{array}{c}\text { Resolution } \\
(\mathrm{m})\end{array}$ & Path/row \\
\hline LT51340332000190BJC00 & $2000-7-8$ & TM & 30 & $134 / 033$ \\
LE71340332012215EDC00 & $2012-8-2$ & ETM+ & $30 / 15$ & $134 / 033$ \\
LE71340332012247PFS00 & $2012-9-3$ & ETM+ & $30 / 15$ & $134 / 033$ \\
\hline
\end{tabular}

by system radiation and the ground control point geometry, and topography correction was accomplished by USGS using SRTM C-band DEM.

\subsubsection{Meteorological data}

The temperature and precipitation data were derived from wireless automatic meteorological station $\left(38.22^{\circ} \mathrm{N} ; 99.88^{\circ} \mathrm{E}, 4452 \mathrm{~m}\right.$ a.s.l.) (Vantage Pro2 Plus), which was placed at the terminus of Shiyi Glacier (at the bedrock) by Qilian Alpine Ecology and Hydrology Research Station, Chinese Academy of Sciences. Combining with snow and rain sampler, which was made by Ceonor, the capacity and sensitivity were 600 and $0.05 \mathrm{~mm}$, respectively. The climate data of Qilian $\left(38.18^{\circ} \mathrm{N}\right.$; $100.25^{\circ} \mathrm{E}, 2789 \mathrm{~m}$ a.s.l. $)$ and Yeniugou $\left(38.14^{\circ} \mathrm{N}\right.$; $99.58^{\circ} \mathrm{E}, 3320 \mathrm{~m}$ a.s.l.) meteorological stations were supplied by the China Meteorological Data Sharing Service System (http://www.cma.gov.cn/ 2011qxfw/2011qsjgx/).

\subsection{Mass-balance calculation and data processing}

\subsubsection{Geodetic mass-balance calculation}

Geodetic observation method determines the volume changes $(\Delta V)$ by comparing glacier surface elevations (DEMs) of different time period, which can be expressed by equation (1). To estimate the glacier mass balance $\left(B_{\text {geo }}\right)$, the geodetic volume changes must be converted into a specific mass balance in the unit $\mathrm{m}$ w.e. using equation (2):

$$
\begin{aligned}
& \Delta V=\sum_{i=1}^{N} \Delta h_{i} r, \\
& B_{\text {geo }}=\frac{\Delta V}{\bar{S}} \cdot \frac{\bar{\rho}}{\rho_{\text {water }}}, \\
& \bar{S}=\frac{S_{t 0}+S_{t 1}}{2},
\end{aligned}
$$

where $N$ is the number of pixels covering the glacier at the maximum extent, $\Delta h_{i}$ is the elevation difference of the two grids at pixel $i$ and $r$ is the pixel size. For equations (2) and (3), where $\bar{\rho}$ is the average density of the volume changes, which denotes the average density of volume changes of $850 \pm 60 \mathrm{~kg} \mathrm{~m}^{-3}$ as recommended by Huss (2013), and $\bar{S}$ is the average glacier area of the two geodetic times, $t 0$ and $t 1$, assuming a linear change (Thibert et al. 2008; Zemp et al. 2013).

\subsubsection{ALS point cloud data processing}

The format of ALS data is las 1.2 and point cloud data processing processes primarily include filtering (classification), man-machine interactive compilation and interpolation. Point cloud filtering cloud removes non-ground point from original data set and was the necessary prerequisite to acquire high-quality DEM, this procedure could be performed using triangulated irregular network (TIN) filtering algorithm in Terrasolid v13 software (running on the MicroStation V8i platform). The basic principle of TIN is that it selects a certain number of ground points to create the original and sparse TIN and then judges other points one by one, if the perpendicular distance and angle between the point and TIN surface are less than the pre-set threshold, the point will be joined into the surface to realise the dense TIN and then recalculate TIN, the iteration continues until no new points of TIN generate or meet the pre-set threshold (Kobler et al. 2007; Belkhouche and Buckles 2011; Fischer 2011). After filtering, man-machine interactive compilation and interpolation were used to eliminate non-ground points which cannot be filtered out automatically (figure 2). On the strength of ArcGIS10.1, a natural neighbourhood interpolation method was used to generate DEM of glacier topography with a resampled spatial resolution of $1 \mathrm{~m}$. The DEM was then down-sampled to $90 \mathrm{~m}$ resolution $(r)$ to coincide with SRTM C-band DEM.

\subsubsection{Co-registration and correction of DEMs}

As SRTM C-band and ALS DEMs were generated using different methods, it consequently resulted in horizontal shifts and vertical biases 


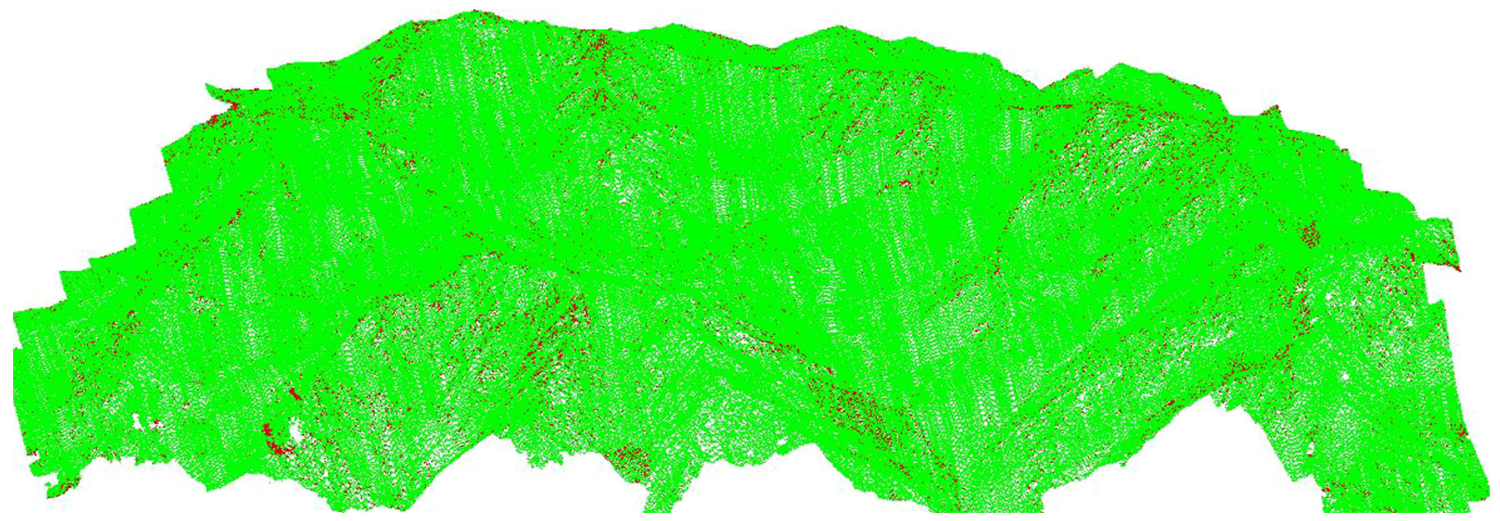

Figure 2. Distribution of ground (green) and non-ground (red) points in the upper Hulugou Basin.
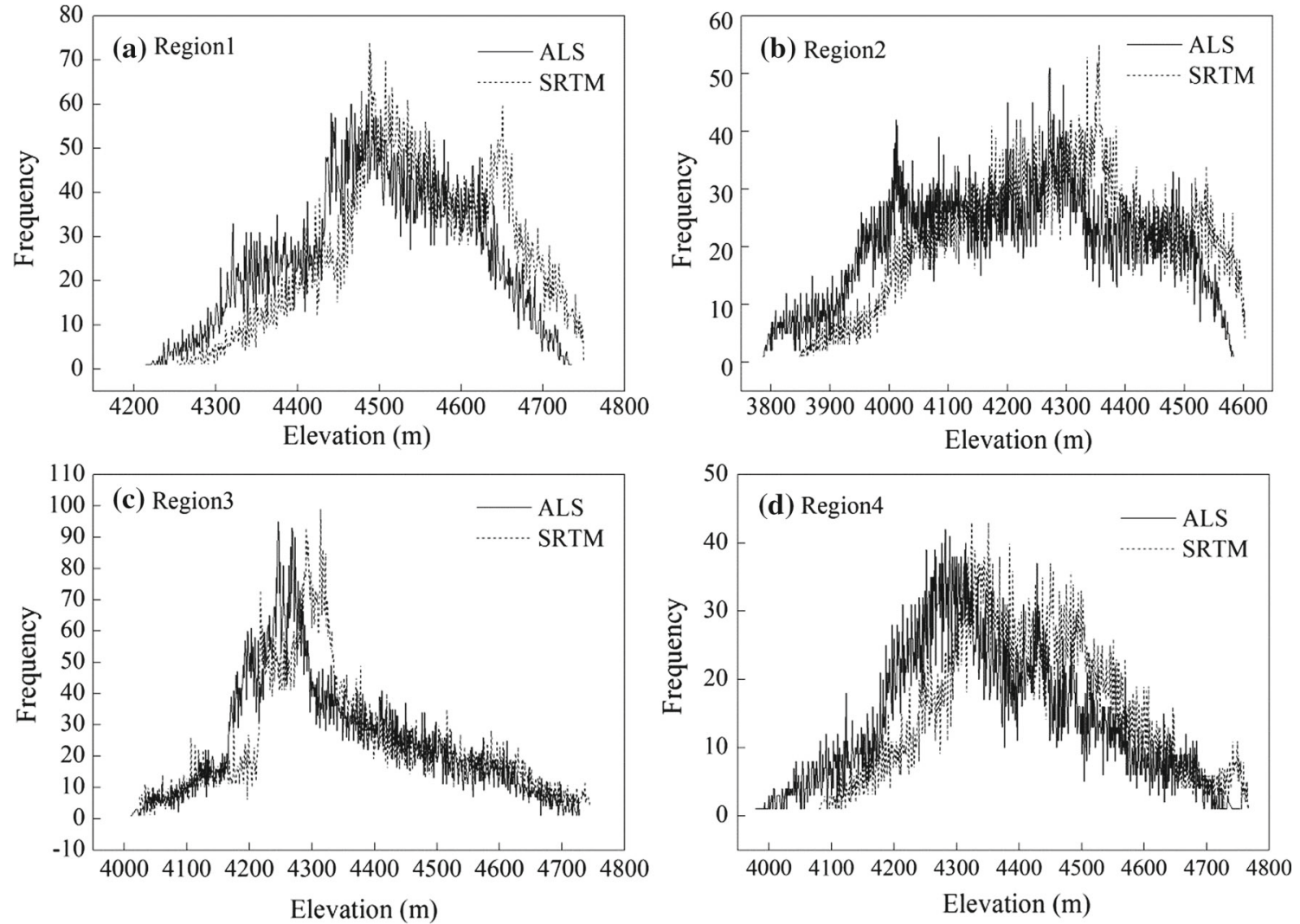

Figure 3. Horizontal shifts of the non-glacierised stable areas.

(Nuth and Kääb 2011). The elevation distributions of four non-glacierised regions demonstrated that two DEMs (SRTM and ALS) of the same regions were offset (figure 3). Therefore, a co-registration must be taken before the subtraction of two DEMs (Gardelle et al. 2013; Ruiz et al. 2017). Due to the relationship of the magnitude $(a)$ of shift vector and the elevation errors to the tangent of the slope of the terrain $(\alpha)$, the elevation differences $(\mathrm{d} h)$ were larger on the steeper slopes, which can be described as

$$
\tan (\alpha)=\mathrm{d} h / a
$$

The value of $\mathrm{d} h$ was opposite on the eastern and western slopes, showing a relationship to the terrain aspect $(\varphi) . \quad \varphi$ is defined as a circular from the north (azimuth) and $a$ can be quantified using a cosine curve. Combining with equation (4), the relationship among elevation difference, slope and aspect can be depicted as:

$$
\begin{gathered}
\mathrm{d} h / \tan (\alpha)=a \cdot \cos (b-\varphi)+c, \\
c=\mathrm{d} h / \tan (\alpha),
\end{gathered}
$$



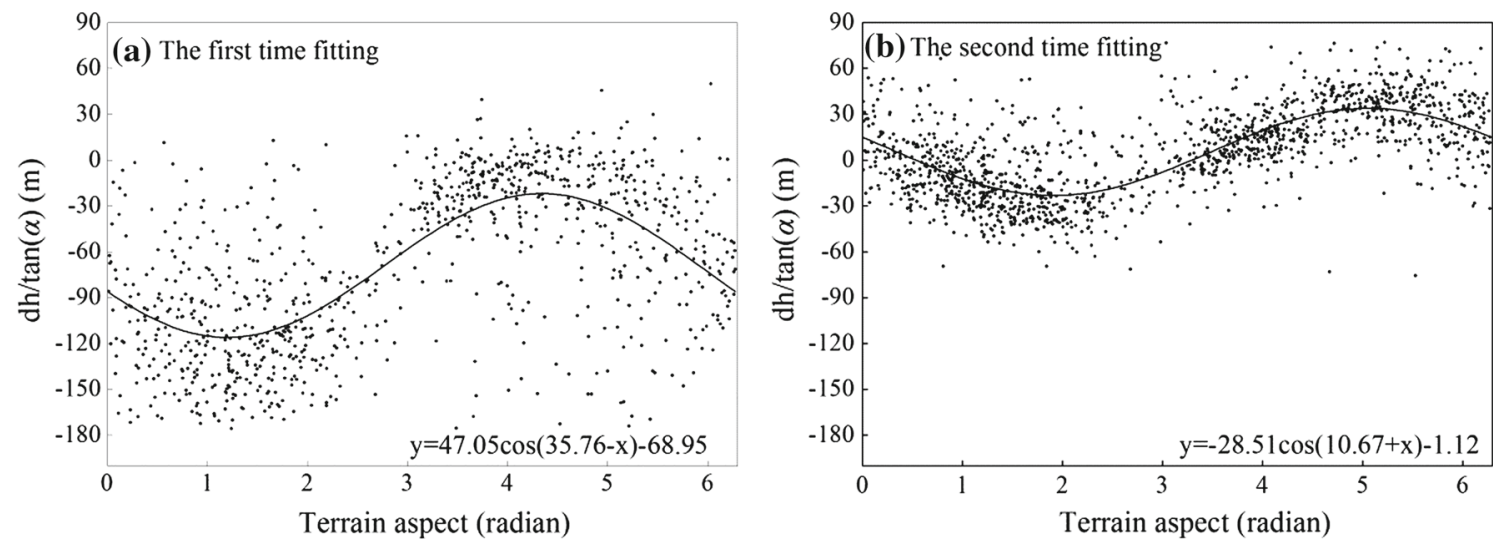

Figure 4. Co-registration between ALS and SRTM C-band DEMs.

$$
\left\{\begin{array}{l}
x=a \cdot \sin (b), \\
y=a \cdot \cos (b), \\
z=c \cdot \tan (\bar{\alpha}),
\end{array}\right.
$$

where $\mathrm{d} h$ is the elevation difference, $a$ is the value of horizontal shift, $b$ is the direction of the shift vector, $\alpha$ is the terrain slope, $\varphi$ is the terrain aspect and $\overline{\mathrm{d} h}$ is the mean elevation difference between the two DEMs. $x, y$ and $z$ are the shift vectors in the corresponding directions (Nuth and Kääb 2011). We set ALS DEM as a reference and SRTM C-band DEM was the offsetting data. We used ArcGIS10.1 and OriginLab software, the non-glacierised stable areas were selected as regions of interest (ROI), elevation difference of the two DEMs, and slope and aspect of ALS DEM of the ROI were extracted, the shift vectors in $x, y$ and $z$ directions were calculated using a cosine model.

The first shifts were 27.49 and $38.18 \mathrm{~m}$ in the direction of west and north, respectively, and the standard deviation of surface elevation changes on the decrease of ROI from 39.68 to $20.22 \mathrm{~m}$. After the second curve fitting (the corresponding shifts were 5.28 and $28.02 \mathrm{~m}$ in the direction of east and north, respectively), the standard deviation was 18.1. When we implemented the third time fitting, standard deviation increased, so the shift vectors of the second time were applied (figure 4).

The different spatial resolution of two DEMs resulted in elevation biases in the mountainous areas that can be corrected using the relationship between elevation differences and maximum curvatures estimated on non-glaciated terrain (Gardelle et al. 2012). A line regression was used to make the correction within an acceptable range of the curvature. For the extreme outliers, the relation between elevation difference and curvature was redundant and must be discarded (figure 5).

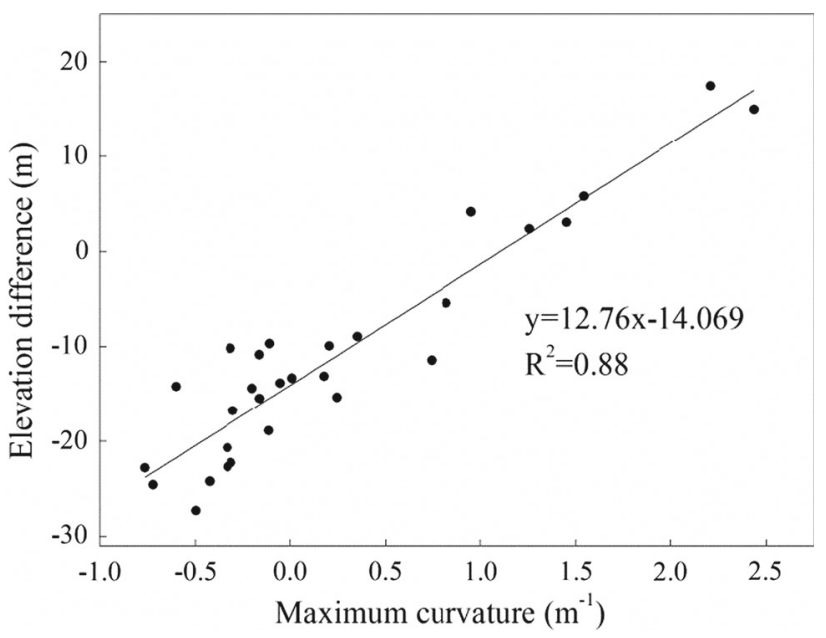

Figure 5. Relationship between elevation difference and the maximum terrain curvature on the non-glacierised stable areas.

\subsection{Uncertainty assessment}

\subsubsection{Evaluation of elevation change uncertainty}

The elevation difference error $\left(E_{\sigma}\right)$ was derived by the pixels of elevation change on the stable offglacier area according to the standard principle of error propagation:

$$
E_{\sigma}=\frac{\mathrm{STDV}}{\sqrt{N}}
$$

where $N$ denotes the number of independent values and STDV is the standard deviation of the ROI. Previous studies demonstrated that the auto-correlation of pixels can be negligible by the distance of 20 pixels (Koblet et al. 2010; Bolch et al. 2011), which was applied in our study. Finally, the uncertainty of elevation change $\left(E_{\mathrm{h}}\right)$ can be determined with the combination of mean elevation 
Table 2. Statistics of original and adjusted vertical errors between DEM difference on the non-glacierised stable areas.

\begin{tabular}{cccccccc}
\hline \multicolumn{2}{c}{ Before correction } & & \multicolumn{2}{c}{ After correction } & & \\
\cline { 1 - 2 }$E_{\mathrm{m}}$ & STDV & & $E_{\mathrm{m}}$ & STDV & & $N$ & $E_{\mathrm{h}}$ \\
\hline-48.02 & 39.68 & & 0.793 & 18.10 & & 1456 & 0.92 \\
\hline
\end{tabular}

difference $E_{\mathrm{m}}$ based on error propagation (Bolch et al. 2011). Calculated values of $E_{\mathrm{h}}$ are given in table 2:

$$
E_{\mathrm{h}}=\sqrt{E_{\sigma}^{2}+E_{\mathrm{m}}^{2}}
$$

\subsubsection{The effect of SRTM penetration}

The penetration of SRTM C-band radar into snow and ice can influence the results of geodetic glacier surface elevation changes. As the penetration depth of the X-band is much shallower than the C-band, the elevation difference between the two data series was considered as approximation for the penetration of SRTM C-band into snow- and ice-covered terrains (Gardelle et al. 2012). Studies showed that the average elevation difference between SRTM Cband and X-band DEMs was about $0.67 \mathrm{~m}$ on non-glacierised areas and $2.00 \mathrm{~m}$ on glacier surface in the Qilian Mountains, respectively (Wang 2013). Whereas limited coverage of SRTM X-band DEM resulted in many uncertainties of the elevation difference. Here, we conservatively assumed that the depth of the penetration was $1.3 \mathrm{~m}$, which was treated as the error of SRTM C-band penetration $\left(E_{\mathrm{d}}\right)$. Note that the ALS surveys were performed at the ablation season, according to field observations of Shiyi Glacier, there was less snow cover on the glacier surface at that time and ALS system also surveyed the glacier surface terrain.

\subsubsection{Density assumption error}

The geodetic surveys provide glacier volume information, which need to be converted into mass using a density assumption. A recommended density assumption of $850 \pm 60 \mathrm{~kg} \mathrm{~m}^{-3}$ is used here, which was provided by Huss (2013) using an empirical firn densification model with idealised surface massbalance forcing. $\pm 60 \mathrm{~kg} \mathrm{~m}^{-3}$ is the uncertainty of density $\left(E_{\rho}\right)$ and represents a $16 \%$ change in the glacier mass balance. The uncertainty of the geodetic mass balance $\left(E_{\mathrm{b}}\right)$ between 2000 and 2012 can be estimated by the law of error propagation
(Ruiz et al. 2017):

$$
E_{\mathrm{b}}=\sqrt{E_{\mathrm{h}}^{2}+E_{\mathrm{d}}^{2}+E_{\rho}^{2}} .
$$

\subsubsection{Accuracy of glacier boundary}

Glacier boundaries were manually delineated from TM/ETM + images in this study. Two parts need to be considered for a sound assessment of the uncertainty in the mapped glacier outlines. One is the interpretation of glacier boundaries, which can be reduced by field validation and glaciological experience. The other one is the uncertainty related to the spatial resolution of the images and errors of image co-registration. Hence, the accuracy of glacier boundary can be evaluated (Hall et al. 2003; Silverio and Jaquet 2005):

$$
\begin{gathered}
U_{\mathrm{L}}=\sqrt{\sum \lambda^{2}}+\sqrt{\sum \varepsilon^{2}}, \\
U_{\mathrm{S}}=2 U_{\mathrm{L}} \sqrt{\sum \lambda^{2}}+\sqrt{\sum \varepsilon^{2}},
\end{gathered}
$$

where $U_{\mathrm{L}}$ is the system uncertainty in the linear dimension, $\lambda$ is the original pixel resolution of the image, $\varepsilon$ is the co-registration errors of the 2000 and 2012 images and $U_{\mathrm{S}}$ is the uncertainty of glacier area. The resulting uncertainty in the glacier area is within $0.003 \mathrm{~km}^{2}$.

\section{Results}

\subsection{Glacier surface elevation changes}

The map of the geodetic elevation changes (figure 6) shows a strong ice loss at lower elevations and smaller thinning to slight thickening at higher elevations for the period 2000-2012, especially for Shiyi Glacier and No. 2. All of these results agree well with the observed results of Shiyi Glacier. The elevation changes of individual glaciers ranged from -7.47 to $-20.30 \mathrm{~m}$ and the average ice-thickness lowering of the six glaciers was $-9.55 \mathrm{~m}$ at a rate of $-0.80 \mathrm{~m} \mathrm{a}^{-1}$. Besides, glaciers with a smaller size (Nos. 4, 5 and 6) showed significant ice loss, with $-14.28 \pm 1.59,-20.30 \pm 1.59$ and $-18.00 \pm 1.59 \mathrm{~m}$ over the period, respectively (table 3 ).

\subsection{Glacier area changes and mass balance}

Table 3 also shows the area and glacier mass balance for each glacier. The total area of the six glaciers had decreased by $23.6 \%$ with a rate of 


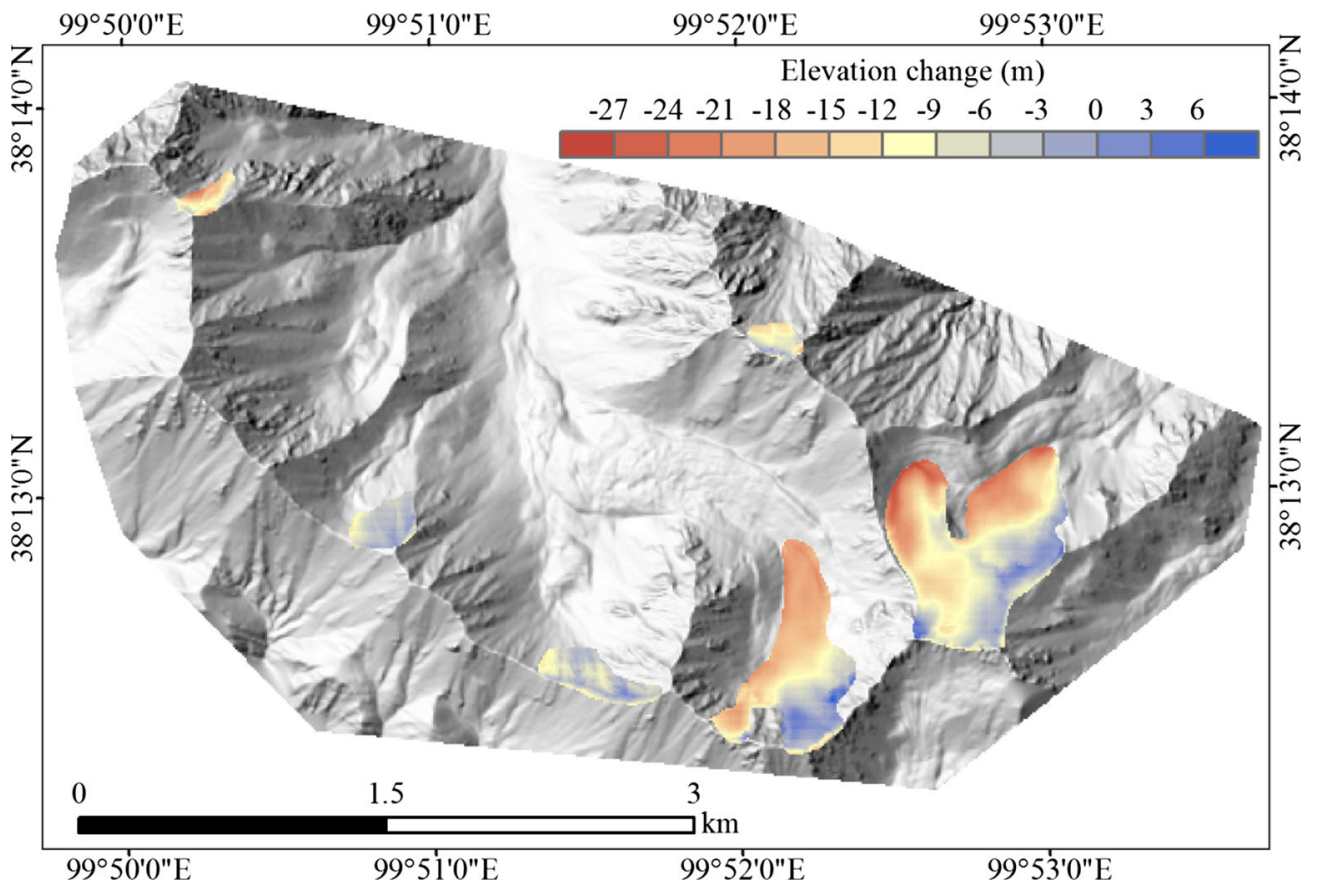

Figure 6. Elevation change map of glaciers in the Hulugou Basin for the period 2000-2012.

Table 3. Area, thickness and mass-balance changes of glaciers in the Hulugou Basin (2000-2012), with the corresponding uncertainty evaluation.

\begin{tabular}{lccccc}
\hline No. & $\begin{array}{c}\text { Area 2000 } \\
\left(\mathrm{km}^{2}\right)\end{array}$ & $\begin{array}{c}\text { Area change } \\
(\%)\end{array}$ & $\begin{array}{c}\Delta h \\
(\mathrm{~m})\end{array}$ & $\begin{array}{c}E_{\mathrm{b}} \\
(\mathrm{m} \text { w.e. })\end{array}$ & $\begin{array}{c}\bar{b}_{a} \\
\left(\mathrm{~m} \mathrm{w.e.} \mathrm{a}^{-1}\right)\end{array}$ \\
\hline 1 (Shiyi Glacier) & 0.55 & 10.9 & -7.47 & \pm 1.35 & -0.53 \\
2 & 0.41 & 25.9 & -9.96 & \pm 1.35 & -0.71 \\
3 & 0.09 & 28.9 & -8.02 & \pm 1.35 & -0.57 \\
4 & 0.06 & 100.0 & -14.18 & \pm 1.35 & -1.00 \\
5 & 0.05 & 34.1 & -20.30 & \pm 1.36 & -1.44 \\
6 & 0.04 & 31.4 & -18.00 & \pm 1.36 & -1.28 \\
Total & 1.20 & 23.6 & -9.55 & \pm 1.35 & -0.68 \\
\hline
\end{tabular}

No. represents the individual glacier, see figure 1 , mean elevation $(\Delta h)$, and annual mass balance $\left(\bar{b}_{a}\right)$ are given.

$0.024 \mathrm{~km}^{2} \mathrm{a}^{-1}$ from 2000 to 2012 . The relative variations in the area of each glacier decreased and the absolute variations increased with the increment of glacier size, which was consistent with the results of glacier variation in the Heihe River Basin (Wang et al. 2011). Shiyi Glacier had the largest size and the area was reduced by $10.9 \%$ at a rate of $0.005 \mathrm{~km}^{2} \mathrm{a}^{-1}$ during the period. One glacier (No. 4) had disappeared completely (table 3).

All glaciers had experienced substantial mass loss and the geodetic mass balance of the six glaciers was $8.12 \pm 1.35 \mathrm{~m}$ w.e. $(-0.68 \pm 0.11 \mathrm{~m}$ w.e. $\mathrm{a}^{-1}$ ) over the period. In addition, the smallest glaciers showed the most negative mass balance (Glacier Nos. 5 and 6). Note that Glacier No.
4 showed a third most negative mass balance although the glacier had vanished; this may be related to subglacial terrain and the distribution of ice thickness. The other three glaciers showed relatively small mass loss and the mass balance of Shiyi Glacier was $-0.53 \pm 0.11 \mathrm{~m}$ w.e. $\mathrm{a}^{-1}$, which was more positive compared to the average mass balance of glaciers in the Hulugou Basin.

\section{Discussion}

\subsection{Comparison of the results to published data}

There are few glaciers with ongoing glaciological mass-balance data over the observed period in 

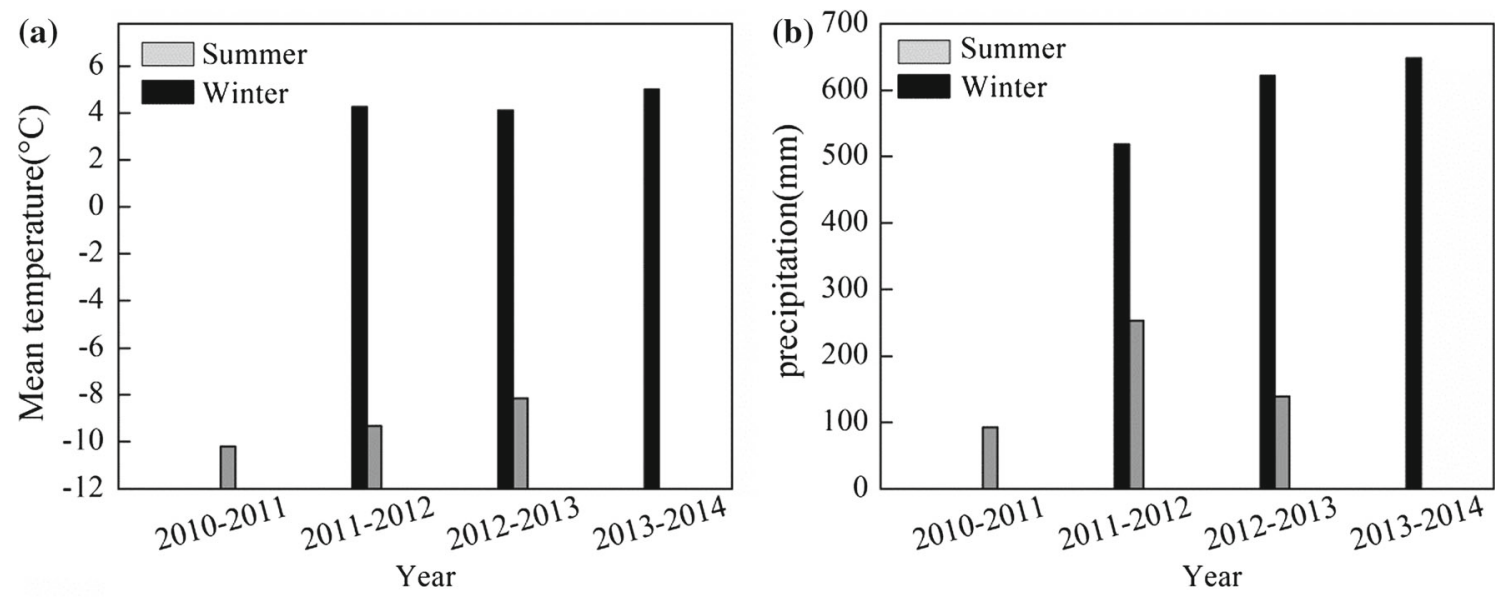

Figure 7. Temperature and precipitation of the automatic weather station at the terminus of Shiyi Glacier.

the Qilian Mountains. Despite some fieldwork implemented for Shiyi Glacier, the glaciological mass balance was limited to recent 5 years (20112016). According to the World Glacier Monitoring Service (WGMS) (http://wgms.ch/), the mean annual mass balance of 41 worldwide reference glaciers was $-0.556 \mathrm{~m}$ w.e. $\mathrm{a}^{-1}$ during the period 2000-2012, which was between the values of Shiyi Glacier $\left(-0.53 \pm 0.11 \mathrm{~m}\right.$ w.e. $\left.\mathrm{a}^{-1}\right)$ and the total six glaciers $\left(-0.68 \pm 0.11 \mathrm{~m}\right.$ w.e. $\left.\mathrm{a}^{-1}\right)$. Specifically, the mass balance of Shiyi Glacier was close to the mean level of worldwide reference glaciers. Urumqi Glacier No. 1 is a summer-accumulationtype glacier (accumulation and ablation occur simultaneously during summer) and the average mass balance was $-0.684 \mathrm{~m}$ w.e. $\mathrm{a}^{-1}$ from 2000 to 2012 , which showed a close match with the mean geodetic mass balance of Hulugou Basin. The climatic data (temperature and precipitation) of the automatic weather station at the terminus of Shiyi Glacier indicated that the precipitation mainly occurred in the summer (May-September) and high temperature also concentrated in the warm season (figure 7). The above-mentioned precipitation and temperature conditions determine the six glaciers are also the summer-accumulation-type glacier (Fang et al. 2015).

Qiyi Glacier is the only one which has discontinuous glaciological mass-balance measurements in the Qilian Mountains. Long-term records showed that the mean mass balance of the glacier was $-0.495 \mathrm{~m}$ w.e. $\mathrm{a}^{-1}$ from 2002 to 2010. By comparison, the mean mass balance of glaciers in the Hulugou Basin was more negative. Studies showed that the surface thinning rates of Yanglonghe glacier No. 1 and Yanglonghe glacier No. 5 were $-0.42 \pm 0.06$ and
$-0.52 \pm 0.06 \mathrm{~m} \mathrm{a}^{-1}$, respectively, during 1977-2007 (Shangguan et al. 2010), which were more positive than the glaciers in the Hulugou Basin. Whereas considering the time span, the mass balance of the two glaciers may be more negative in recent $12 \mathrm{yr}$. The comparative results revealed the mass balances of the investigated glaciers were valid and glaciers in Qilian Mountains had experienced an accelerated shrinkage.

\subsection{Climate variability and trends}

Precipitation and temperature and their interannual changes are the main factors controlling glacier mass balance. As summer-accumulationtype glaciers, the processes of mass balance were mainly dominated by summer temperature (MaySeptember) and annual precipitation. The regional (Qilian and Yeniugou meteorological stations) summer temperature indicated that the Hulugou Basin had experienced an overall warming trend during the last decade and the increased rate of temperatures of the two stations was greater than $0.04^{\circ} \mathrm{C} \mathrm{a}^{-1}$ (figure 8). In the Qilian Mountains, the temperature also increased significantly since the 1990s; the increased precipitations had great annual variations and mainly occurred in summer, which was adverse to glacier accumulation. Oerlemans (2005) pointed out that a $25 \%$ increase in annual precipitation is typically needed to compensate for the mass loss due to a uniform $1 \mathrm{~K}$ warming by using a mass-balance model for a large number of glaciers, indicating that glaciers experienced substantial mass loss in the Hulugou River as a consequence of regional climate change. 

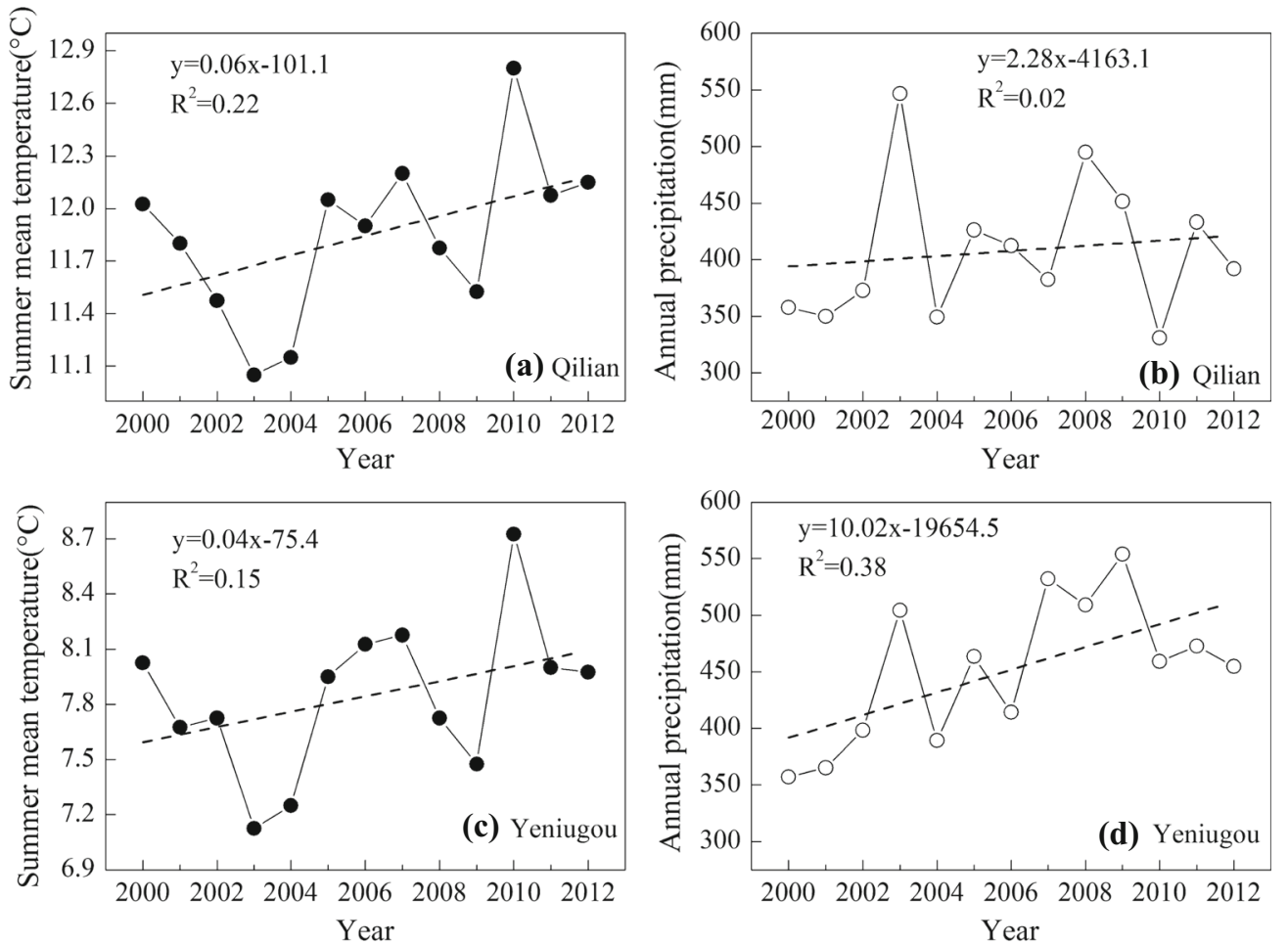

Figure 8. Summer mean temperature and annual precipitation of Qilian and Yeniugou meteorological stations around the Hulugou Basin.

\section{Conclusions and outlook}

Based on a series of Landsat images, SRTM C-band (2000) and ALS (2012) DEMs, here we present glacier area and surface elevation, and glacier-wide mass-balance changes of six very small glaciers in the Hulugou Basin. During the period 2000-2012, the six glaciers had lost $23.6 \%$ of their surface area at a rate of $0.024 \mathrm{~km}^{2} \mathrm{a}^{-1}$, and the area of Shiyi Glacier decreased by $10.9 \%$ at a rate of $0.005 \mathrm{~km}^{2}$ $\mathrm{a}^{-1}$. The geodetic mass balance calculated from the two temporal DEMs showed that the average mass balance of the six glaciers was $-0.68 \pm 0.11 \mathrm{~m}$ w.e. $\mathrm{a}^{-1}$. The smallest glaciers showed the most negative mass balance and the mass balance of Shiyi Glacier was $-0.53 \pm 0.11 \mathrm{~m}$ w.e. $\mathrm{a}^{-1}$, which was more positive than the mean mass balance of the glaciers in the Hulugou Basin. Regional climate (summer mean temperature and annual precipitation) records indicated that the Hulugou Basin had experienced an overall warming trend from 2000 to 2012 . The trend may at least partly explain the generalised glacier mass loss throughout the region in the last decade. As the response of glacier retreat to climate change is delay, these glaciers will continue to shrink in the future even without further climate warming. Whereas very small glaciers are dominated in this region and the Qilian Mountains, and due to their highly variable characteristics, the influence of glacier shrinkage on the runoff is still restricted to qualitative or semi-qualitative analysis. A continuous monitoring network of Shiyi Glacier and hydrology in the Hulugou Basin is essential to predict the evolution of glaciers and their impact on water resources.

\section{Acknowledgements}

This study was supported by the Strategic Priority Research Program of the Chinese Academy of Sciences (XDA2006020103), National Natural Science Foundation of China (Nos. 91425303; 41471058; 41721091), the Key Research Program of Frontier Sciences of Chinese Academy of Sciences (No. QYZDB-SSW-SYS024) and the West Light Program for Talent Cultivation of Chinese Academy of Sciences. We are very grateful to USGS (US Geological Survey) for the Landsat images and SRTM C-band DEM and China Meteorological Data Sharing Service System for meteorological data. We also thank the Cold and Arid Regions Sciences Data Center at Lanzhou for the ALS point cloud data. 


\section{References}

Belkhouche M Y and Buckles B 2011 Iterative tin-based automatic filtering of sparse LiDAR data; Remote Sens. Lett. 2(3) 231-240, https://doi.org/10.1080/01431161. 2010.515266

Bolch T, Pieczonka T and Benn D I 2011 Multi-decadal mass loss of glaciers in the Everest area (Nepal Himalaya) derived from stereo imagery; Cryosphere 5 349-358, https://doi.org/10.5194/tc-5-349-2011.

Cogley J G 2009 Geodetic and direct mass-balance measurements: Comparison and joint analysis; Ann. Glaciol. $\quad \mathbf{5 0 ( 5 0 ) \quad 9 6 - 1 0 0 , \quad h t t p s : / / d o i . o r g / 1 0 . 3 1 8 9 / ~}$ 172756409787769744.

Cogley J G, Hock R, Rasmussen L A, Arendt A A, Bauder A, Braithwaite R J, Jansson P, Kaser M, Möller G, Nicholson L and Zemp M 2011 Glossary of glacier mass balance and related terms; IHP-VII technical documents in hydrology No. 86, IACS Contribution No. 2, UNESCO-IHP, Paris.

Fang X Y, Li Z Q, Bernd W, Gao $\mathrm{S}$ and Chen $\mathrm{R} S$ 2015 Physical energy-balance and statistical glacier melting models comparison and testing for Shiyi Glacier, Heihe River Basin, Qilian Mountains, China; J. Glaciol. Geocryol. 37(2) 336-350 (in Chinese).

Fischer A 2011 Comparison of direct and geodetic mass balances on a multi-annual time scale; Cryosphere 5 107-124, https://doi.org/10.5194/tc-5-107-2011.

Gardelle J, Berthier E and Arnaud Y 2012 Impact of resolution and radar penetration on glacier elevation changes computed from DEM differencing; J. Glaciol. 58(208) 419-422, https://doi.org/10.3189/2012JoG11J175.

Gardelle J, Berthier E, Arnaud Y and Kääb A 2013 Regionwide glacier mass balances over the Pamir-KarakoramHimalaya during 1999-2011; Cryosphere 7 1263-1286, https://doi.org/10.5194/tc-7-1236-2013.

Hall D K, Bayer K and Schfner W 2003 Consideration of the errors inherent in mapping historical glacier positions in Austria from ground and space 1893-2001; Remote Sens. Environ. 86 566-577, https://doi.org/10. 1016/S0034-4257(03)00134-2.

Hartzell P J, Gadomski P J, Glennie C L, Finnegan D C and Deems J S 2015 Rigorous error propagation for terrestrial laser scanning with application to snow volume uncertainty; J. Glaciol. 61(230) 1147-1158, https://doi. org/10.3189/2015JoG15J031.

Helfricht K, Kuhn M, Keuschnig M and Heilig A 2014 LiDAR snow cover studies on glaciers in the Ötztal Alps (Austria): Comparison with snow depths calculated from GPR measurements; Cryosphere 8 41-57, https://doi. org/10.5194/tc-8-41-2014.

Huss M 2013 Density assumptions for converting geodetic glacier volume change to mass change; Cryosphere 7877 887, https://doi.org/10.5194/tc-7-877-2013.

Huss M and Fischer M 2016 Sensitivity of very small glaciers in the Swiss Alps to future climate change; Front. Earth Sci. 4(34) 1-17, https://doi.org/10.3389/ feart.2016.00034.

Intergovernmental Panel on Climate Change (IPCC) 2013 Climate change 2013: The physical science basis. Contribution of working group I to the fifth assessment report of the intergovernmental panel on climate change;
Cambridge University Press, Cambridge, UK and New York, USA, 1535p.

Joerg P, Morsdorf F and Zemp M 2012 Uncertainty assessment of multi-temporal airborne laser scanning data: A case study at an Alpine glacier; Remote Sens. Environ. 127 118-129, https://doi.org/10.1016/j.rse.2012.08. 012.

Kobler A, Pfeifer N, Ogrinc P, Todorovski L, Ostir K and Dzeroski S 2007 Repetitive interpolation: A robust algorithm for DTM generation from Aerial Laser Scanner Data in forested terrain; Remote Sens. Environ. 108 9-23, https://doi.org/10.1016/j.rse.2006.10.013.

Koblet T, Gärtner-Roer I, Zemp M, Jansson P, Thee P, Haeberli W and Holmlund P 2010 Reanalysis of multitemporal aerial images of Storglaciären, Sweden (1959-99) - part 1: Determination of length, area, and volume changes; Cryosphere 4 333-343, https://doi.org/10.5194/ tc-4-333-2010.

Li X, Liu S M, Ma M G, Xiao Q, Liu Q H, Jin R, Che T, Wang W Z, Qi Y, Li H Y, Zhu G F, Guo J W, Ran Y H, Wen J G and Wang S G 2012 HiWATER: An integrated remote sensing experiment on hydrological and ecological processes in the Heihe River Basin; Adv. Earth Sci. 27(5) 481-498 (in Chinese).

Liu S Y, Yao X J, Guo W Q, Xu J L, Shuangguan D H, Wei J F, Bao W J and Wu L Z 2015 The contemporary glaciers in China based on the Second Chinese Glacier Inventory; Acta Geogr. Sin. 70(1) 3-16 (in Chinese).

Muskett R R, Lingle C S, Tangborn W V and Rabus B T 2003 Multidecadal elevation changes on Bagley Ice Valley and Malaspina Glacier, Alaska; Geophys. Res. Lett. 30(16) 1857, https://doi.org/10.1029/2003GL017707.

Nuth C and Kääb A 2011 Co-registration and bias corrections of satellite elevation data sets for quantifying glacier thickness change; Cryosphere 5 271-290, https://doi.org/ 10.5194/tc-5-271-2011.

Oerlemans J 2005 Extracting a climate signal from 169 glacier records; Science 308(5722) 675-677, https://doi. org/10.1126/science.1107046.

Piermattei L, Carturan L and Guarnieri A 2015 Use of terrestrial photogrammetry based on structure-from-motion for mass-balance estimation of a small glacier in the Italian Alps; Earth Surf. Process. Land. 40(13) 1791-1802, https://doi.org/10.1002/esp.3756.

Pu J C, Yao T D, Duan K Q, Sakai A, Fujita K and Matsuda Y 2005 Mass balance of the Qiyi glacier in the Qilian Mountains: A new observation; J. Glaciol. Geocryol. 27(2) 199-204 (in Chinese).

Rabus B, Eineder M and Roth A 2003 The shuttle radar topography mission - A new class of digital elevation models acquired by spaceborne radar. J. Photogramm. $\quad \mathbf{5 7 ( 4 )} \quad 241-262$, https://doi.org/10.1016/ S0924-2716(02)00124-7.

Ruiz L, Berthier E, Viale M, Pitte $\mathrm{P}$ and Masiokas M H 2017 Recent geodetic mass balance of Monte Tronador Glaciers, northern Patagonian Andes; Cryosphere 11619 634, https://doi.org/10.5194/tc-11-619-2017.

Shangguan D H, Liu S Y, Ding Y J, Zhang Y S, Li J, Li $\mathrm{X}$ Y and $\mathrm{Wu} \mathrm{Z} 2010$ Changes in the elevation and extent of two glaciers along the Yanglonghe River, Qilian Shan, China; J. Glaciol. 56(196) 309-317, https://doi.org/10. 3189/002214310791968566. 
Silverio W and Jaquet J M 2005 Glacial cover mapping (1987-1996) of the Cordillera Blanca (Peru) using satellite imagery; Remote Sens. Environ. 95(3) 342-350, https:// doi.org/10.1016/j.rse.2004.12.012.

Sun M P, Liu S Y, Yao X J, Guo W Q and Xu J L 2015 Glacier changes in the Qilian mountains in the past half century: Based on the revised First and Second Chinese Glacier Inventory; Acta Geogr. Sin. 70(9) 1402-1414 (in Chinese).

Thibert E, Blanc R, Vincent C and Lane S N 2008 Instruments and methods glaciological and volumetric massbalance measurements: Error analysis over 51 yr for Glacier de Sarennes, French Alps; J. Glaciol. 54(186) 522-532, https://doi.org/10.3189/002214308785837093.

Wang Y Z 2013 A study of glacier volume changes in Qilian Mountains over the last decade; Master thesis, University of Chinese Academy of Sciences, Beijing, pp. 22-24 (in Chinese).

Wang P Y, Li Z Q, Gao W Y, Yan D H, Bai J Z, Li K M and Wang L 2011 Glacier changes in the Heihe River Basin over the past 50 years in the context of climate change; Resour. Sci. 33(3) 399-407 (in Chinese).

Wehr A and Lohr U 1999 Airborne laser scanning - An introduction and overview; ISPRS J. Photogramm.
Remote Sens. 54 68-82, https://doi.org/10.1016/ S0924-2716(99)00011-8.

WGMS 2017 Global glacier change bulletin No. 2 (2014 -2015); ICSU(WDS)/IUGG(IACS)/UNEP/UNESCO/ WMO, World Glacier Monitoring Service, Zurich, Switzerland, 244p, https://doi.org/10.5904/wgms-fog-2017-10.

Zemp M, Thibert E, Huss M, Stumm D, Rolstad Denby C, Nuth C, Nussbaumer S U, Moholdt G, Mercer A, Mayer C, Joerg P C, Jansson P, Hynek B, Fischer A, Escher-Vetter H, Elvehøy H and Andreassen L M 2013 Reanalysing glacier mass-balance measurement series; Cryosphere $\mathbf{7}$ 1227-1245, https://doi.org/10.5194/tc-7-1227-2013.

Zemp M, Frey H, Gärtner-Roer I, Nussbaumer S U, Hoelzle M, Paul F, Haeberli W, Denzinger F, Ahlstrøm A P, Anderson B, Bajracharya S, Baroni C, Braun L N, Cáceres B E, Casassa G, Cobos G, Dávila L R, Delgado Granados H, Demuth M N, Espizua L, Fischer A, Fujita K, Gadek B, Ghazanfar A, Hagen J O, Holmlund P, Karimi N, Li Z Q, Pelto M, Pitte P, Popovnin V V, Portocarrero CA, Prinz R, Sangewar C V, Severskiy I, Sigurdsson O, Soruco A, Usubaliev R and Vincent C 2015 Historically unprecedented global glacier decline in the early $21 \mathrm{st}$ century; J. Glaciol. 61(228) 745-762, https://doi.org/10. 3189/2015JoG15J017.

Corresponding editor: NAVIN JUYAL 